\title{
FORCED STERILIZATION AND ABORTION IN JAPAN: FAMILY AND CONSTITUTION
}

\author{
Yuichiro Tsuji \\ University of Tsukuba
}

\begin{abstract}
This study analyzes the fight between the Japanese judiciary and legislature. In Japan, under the ex-Eugenic Protection Act, disabled people were obligated to undergo sterilization procedures for about 20 years. This surprising Act was established in 1948 and enabled doctors to sterilize people in order to eliminate hereditary diseases; they could also perform this procedure on physically or developmentally disabled people without their consent. The 2016 Committee on the Elimination of Discrimination against Women advised that research and compensation is urgent and necessary, but the government stated that it was a legal medical operation, and no compensation was necessary. Even under concrete judicial review, the judiciary in Japan may exercise its power to provide remedies for minorities who cannot amend statutes in the political process, or their constitutional rights will be infringed upon. This study argues that even concrete judicial reviews work to prevent serious damage before it occurs. This study will use a legal approach to review the first voting rights decision, as well as several decisions that are relevant to families in Japan. Under a concrete judicial review of the Japanese constitution, a plaintiff needs to bring a dispute in law to the court and allege that the statute or administrative disposition infringes on their human rights as provided for in the constitution. If there is no statute in the case, it is very difficult for a plaintiff to compel the legislature to pass the statute. If the legislature does not function well, the judiciary is obligated to find a way to encourage the legislature or the government to provide a remedy. The judiciary cannot compel the legislature, but may show some of the steps that it follows in its decisions.
\end{abstract}

Keywords: judicial review, Japan, sterilization, concrete review, compensation, minority.

\section{INACTION OF LEGISLATURE AND VOTING RIGHTS}

The legislature had ample discretion to pass, amend, or abolish statutes under Article $41^{1}$ of the constitution. Voters may ask the legislature to take action in political processes. Representatives owe voters political, not legal, accountability. ${ }^{2}$ There is no system for voters to fire politicians in the Japanese Diet (parliament).

Article $15^{3}$ of the constitution provides universal suffrage, but the requirements for voting are provided in the Public Offices Election Act (POEA). ${ }^{4}$ A 2005 Japanese Supreme Court decision ${ }^{5}$




ruled that it is unconstitutional that no provisions of the POEA ${ }^{6}$ provide for voters living outside of Japanese territory.

The Court explained that the legislature may not restrict people's voting rights except for those who seek to damage the fairness of an election. The legislature is required by compelling interest to restrict voting rights to maintain the fairness of elections. The Court declared for more than ten years that legislative inaction was illegal and this did not have a compelling interest for the legislature, which was thus liable under the State Redress Act. ${ }^{7}$ In 2006, the legislature amended the POEA. In this case, the plaintiff used new litigation in the revised Administrative Case Litigation Act (ACLA). ${ }^{8}$

In 2004, the legislature amended the Administrative Case Litigation Act to expand the scope of judicial review. First, litigation in public law-related actions ${ }^{9}$ is an action relating to an original administrative disposition or administrative disposition on appeal that confirms or creates a legal relationship between parties, wherein either party to the legal relationship shall stand as a defendant pursuant to the provisions of laws and regulations, an action for a declaratory judgment on a legal relationship under public law and any other action relating to a legal relationship under public law. ${ }^{10}$

The 2005 decision approved this relatively new litigation that allows for preventive action before damage arises.

Second, Article $3(5)^{11}$ of the ACLA allows to sue in an action for the declaration of the illegality of inaction. A plaintiff asked the Court to declare the illegality of legislative inaction, but the Court rejected the appeal because the legislature had already amended the POEA.

The 2005 decision narrows the wide discretion of legislators. The Japanese Supreme Court may review the restriction of voting rights.

In general, the mission of constitutional review in Japan is to provide remedies in concrete cases. The 2005 Supreme Court decision makes lawyers, who bring forward suits to seek action from the legislature, aware of the expectations of new litigations in the ACLA. The revised ACLA also established mandamus action that compels the government to make dispositions. Article $37-2^{12}$ of the ACLA provides two litigations: one relates to who is eligible to apply, and the other relates to who is not eligible. Today, these two kinds of litigation enable citizens to bring forth actions to seek a declaration or to compel the government to perform an action.

Japanese public law professors can now review the possibility of new litigations in the ACLA. ${ }^{13}$ The other cases relating to voting rights are held by two high courts. They reviewed legislative discretion to restrict the voting rights of prisoners who were sentenced to imprisonment. Article 11(1)ii ${ }^{14}$ of the POEA restricts voting rights of prisoners who were sentenced to imprisonment.

In September 2013, the Osaka High Court ${ }^{15}$ dismissed the claim due to a lack of interest in the confirmation of the illegality of inaction. This reasoning is very tricky. The Osaka High Court ruled




that there was legally no damage as a result of the inaction of the legislature under the State Redress Act. The court ruled that the POEA's restriction of voting rights in general was illegal on the grounds that they are merely prisoners, and it was illegal because they did not have access to absence voting either. The court explained that the legislature needed compelling interest to restrict voting rights and explained that it is unfair to exclude prisoners. They did so by noting that the constitutional referendum does not exclude prisoners who were sentenced to imprisonment. Prisoners may receive information from the official gazette or television about elections. It is possible to set up an early voting place in prison before the start of official voting.

The Osaka High Court decision is very technical by encouraging the legislature to revise the procedures for voting, such as postal voting.

In December 2013, the Tokyo High Court ${ }^{16}$ ruled that the same provision of the Public Official $\mathrm{Act}^{17}$ for the proportional election of the House of Councilors was reasonable and was not an arbitrary and capricious exercise of legislative power. The citizens who lost their case appealed to the Supreme Court. In 2014, the Supreme Court dismissed the appeal to seek confirmation of illegal election.

Under concrete judicial review in Japan, Article $3(1)^{18}$ of the Court Act provides for disputes on laws and is similar to the term "case and controversy" in Article 3 of the U.S. Constitution. This aims to protect individual rights. The ACLA provides actions for the judicial review of administrative dispositions in Article $3^{19}$ and public law-related action in Article $4 .^{20}$ This is called subjective litigation and serves the purpose of protecting the interests of individuals.

Even under concrete review, the ACLA provides for citizen action and interagency action, called objective litigation, in Articles $5^{21}$ and $6 .{ }^{22}$ Citizen action seek[s] the correction of an act conducted by an agency of the State or of a public entity which does not conform to laws, regulations, and rules, which is filed by a person based on his/her status as a voter or any other status that is irrelevant to his/her legal interest. ${ }^{23}$

It aims to correct illegal administrative activities and keep legal order. Articles $204^{24}$ and $205(1)^{25}$ of the POEA provides procedures for voters to argue that election administration commissions were illegal and void. By using these provisions in this case, the citizens argued that it is unconstitutional for Articles 11(1)ii and $\mathrm{iii}^{26}$ of the POEA to uniformly deprive prisoners of their voting rights who was sentenced to imprisonment.

The Supreme Court ruled that the purpose of Articles 204 and 205(1) is to provide litigation for the illegality of the election administrative commission, but did not anticipate litigation in that the plaintiff asked the court to rule on the illegality of the POEA itself. The Supreme Court explained

16 Tokyo Kotō Saibansho [Tokyo High Ct.] Sept. 14, 2005, Heisei 13 (gyo tsu) no. 82, 59(7) Saikō Saibansho Minji Hanreishu [Minshu] 2087.

17 Kōshoku Senkyo Hō [Japanese Public Officer Election Act], art. 11(1)ii.

18 Gyosei jiken soshou Hō [Administrative Case Litigation Act], art. 3(1).

19 Ibid., art.3.

20 Ibid., art.4.

21 Ibid., art.5.

22 Ibid., art.6.

23 Ibid.

24 Kōshoku Senkyo Hō [Japanese Public Officer Election Act], art. 204.

25 Ibid., art. 205(1).

26 Ibid., art. 11(1)ii and iii. 
that only a person who has his or her voting rights restricted may bring forth a suit to seek a remedy from the court. A third party may not bring forth a suit. Justice Katsumi Chiba ${ }^{27}$ wrote a concurring opinion criticizing the majority. Under concrete judicial review, he argued that the court should have narrowed its scope and avoided an unnecessary decision.

These voting decisions are a clue to the review of family cases, such as those relating to physically or developmentally disabled persons, and those who carry hereditary diseases. These people are marginalized in society, and their families hide their existence because they feel shame for their family honor. In the next section, it is argued that the Court is vital in shaping the consciousness of families in Japanese society.

\subsection{ALS and elections}

The ALS (Amyotrophic lateral sclerosis) decision ${ }^{28}$ illustrates the difficulty of bringing forth a suit alleging legislative inaction in a Japanese court. In this case, the POEA did not allow for postal voting, and required that voters use their own handwriting when voting. ${ }^{29}$ ALS patients argued that legislative inaction is illegal under the State Redress Act.

The Tokyo district court held that the government was not liable even though it is unconstitutional to restrict the voting rights of people with ALS. It explained that the government is liable if the legislature illegally violated a clear term of the constitution. The court denied any damage to the rights of people with ALS because it was not clear that the legislature violated a clear term of the constitution. The Tokyo district court also rejected the argument for the confirmation of inaction of the amendment to the POEA because it was not a legal dispute under Article $3^{30}$ of the Court Act.

\subsection{Down syndrome}

The Osaka High Court decision for the restriction of the voting rights of prisoners followed a famous decision of the Tokyo district court regarding a case ${ }^{31}$ about Down syndrome.

In this case, a woman with Down syndrome was born in 1962 and diagnosed with Down syndrome three months after she was born. When she was 47 years old, she used the guardian system to designate her father as her guardian. Ex-Article $11^{32}$ of the POEA deprived her of her voting rights. Under the adult guardianship system, the adult ward was deprived of voting rights.

She brought forward a public law-related action under Article $4^{33}$ of the ACLA to the Tokyo district court for confirmation of her voting rights.

After the Meiji constitution ${ }^{34}$ was amended to the current constitution, the Civil Code was revised and has ruled that a person who is non compos (mentis) is deemed incompetent and should

27 Chiba, J., concurring.

28 Kōshoku Senkyo Hō [Japanese Public Officer Election Act], art. 68.

29 Tokyo Chihō Saibansho [Tokyo Dist. Ct.] Nov. 28, 2002, Heisei 12 (wa) no. 502, 1114 Hanrei Taimuz [Hanta] 93 (Japan).

30 Saibansho Hō [Court Act], law no. 59/1947, art. 3.

31 Tokyo Chihō Saibansho [Tokyo Dist. Ct.] March 14, 2013, Heisei 23 (gyo u) no. 63, 1388 Hanrei Taimuz [Hanta] 62.

32 Kōshoku Senkyo Hō [Japanese Public Officer Election Act], art. 11 (abolished).

33 Gyosei jiken soshou Hō [Administrative Case Litigation Act], art. 4.

34 Dai Nihon Teikoku Kenpō (Meiji Kenpō) [Meiji Constitution]. 
be protected. ${ }^{35}$ The incompetent person may not manage property or legally enter into contracts. In 1999, the Civil Code was revised into the current guardian system. Ex-Article 11 of the POEA provides that an adult ward has no voting rights.

In March 2013, the Tokyo district court explained that the ability to manage property and the ability to make political decisions is completely different. There is no compelling interest to restrict the voting rights of a person with Down syndrome such as undue influence on a fair election or a blank ballot. A person with a guardian may be eligible to exercise their voting rights.

Surprisingly, 74 days after its decision, the legislature amended POEA to abolish the denial of voting rights for persons with adult guardianship. Under Japanese constitutional law, the 1985 Supreme Court case ${ }^{36}$ illustrates that there is no specific time limit for legislative action after an unconstitutional decision. This case involved a person who was injured while shoveling snow from his roof. Following his injury, the individual could not leave his home to vote, but the POEA had abolished home voting because the legislature believed that at the time, home voting was being abused. The 1985 decision $^{37}$ held that it in very limited cases will the judiciary declare the illegality of legislative inaction. Thus, the legislature has wide discretion to pass or abolish a statute. This Down syndrome case illustrates the positive action of the legislature. It is not promising to expect immediate legislative action. ${ }^{38}$

The Tokyo district court decision was a straightforward and clear message from the judiciary to the legislature. The court decision taught the legislature how to respond to its decision. The legislature deleted the provision immediately after the decision. The POEA defines voting requirements and procedures. The POEA may in the future state that disabled persons may exercise their voting rights by gestures or multiple-choice questions in order to more easily exercise their right to vote, but that matter is still subject to legislative discretion.

\subsection{Sterilization of disabled people}

Even though the current constitution was established 71 years ago and most statutes were amended, one terrible statute remained. In 1948, the legislature passed the Eugenic Protection Act ${ }^{39}$ and adopted the forced sterilization of physically and developmentally disabled people, and those with Hansen and hereditary diseases. The Eugenic Protection Act followed the National Eugenic Act which was modeled on the Nazi Germany statute of $1940 .{ }^{40}$ The purpose was to prevent the birth of supposedly unwanted people, and doctors performed sterilizations and abortions to achieve this goal. Doctors

35 OHKAWA, S.: Meiji Minpō ni okeru Koui Nouryoku no seigen [Restriction of legal capacity under Meiji Civil Code]. In: Ritsumeikan Ho gaku, vol. 240, 1995. Available at http://www.ritsumei.ac.jp/acd/cg/law/lex/95-2/ookawa.htm (accessed on $5^{\text {th }}$ November 2018).

36 Saikō Saibansho [Sup. Ct.] Nov. 21, 1985, Showa 50(0) no. 1240, 39(7) Saikō Saibansho Minji Hanreishu [Minshu] 1512.

37 Ibid.

38 TSUJI, Y.: Reflection of Public Interest in the Japanese Constitution: Constitutional Amendment. In: Denver Journal of International Law \& Policy, Vol. 46, 2018, 2, p. 159, 163.

TSUJI, Y.: Decisions That Declared Laws Unconstitutional And Their Impact On Japanese Families. In: ILSA Journal of International \& Comparative Law, Vol. 24, 2017, 1, Article 2. Available at: https://nsuworks.nova.edu/ilsajournal/vol24/ iss $1 / 2$ (accessed on $5^{\text {th }}$ November 2018).

39 Yusei hogo Hō [Eugenic Protection Act], law no. 165 (1948) (abolished).

40 The Mainichi Shimbun, Kagakuno na no motoni [Under the name of science] (8, June, 2018). Available at: https://mainichi.jp/articles/20180607/ddm/041/040/141000c(accessed on $5^{\text {th }}$ November 2018). 
had a duty to report hereditary diseases to the committee of Eugenic protection. A notice from the Ministry of Health and Welfare ${ }^{41}$ announced in 1953 that doctors may operate without the consent of their patients and allowed for deception and physical restraint. Doctors performed these procedures and were reviewed by their prefectural board.

In 1996, legislature abolished most provisions of this Act. A report by the Japanese Bar Association $^{42}$ reported that 59000 abortions and 25000 sterilizations were performed.

In June 2017, Miyagi prefecture ${ }^{43}$ found one record of compulsory sterilization that was performed on a developmentally disabled person. In Kanagawa prefecture, one record noted that a teenager was targeted on the grounds that she could not clean herself when menstruating. The other record showed that a forced sterilization was performed on a diligent worker who was diagnosed with schizophrenia but recovered six months later.

The government has not paid any compensation and announced that these actions were legal at the time. One man filed a suit seeking damages under the State Redress Act for forced sterilization when he was 20 years old. ${ }^{44}$ We are awaiting the outcome of this litigation.

\section{INACTION OF GOVERNMENT AND BLANK STATUTES}

Statutes established by the legislature are just a collection of words. Statutes need the administrative branch to implement them. This section illustrates governmental inaction even though the legislature wrote the statute, but caused serious damage to human lives. This is illustrated by one of the most famous cases, called Minamata disease.

\subsection{Environmental pollution and governmental inaction}

Minamata disease is one of the four major pollution diseases in Japan. In this case, mercury pollution occurred in Kumamoto prefecture. Later, as residents moved out of the area, latent diseases were actualized. This environmental pollution case illustrates the liability of the administrative and legislative branch for their inaction.

In this case, the legislature prepared two statutes ${ }^{45}$ for water pollution in 1958. The purpose of these two Acts was to prevent a serious dispute between fisheries and factories. They failed to pro-

41 The Mainichi Shimbun, Editorial: Kyosei funin shujutu no chousa [Editorial: investigation on forced abortion]. Available at: https://mainichi.jp/articles/20180513/ddm/005/070/003000c (accessed on $5^{\text {th }}$ November 2018).

42 Japan Bar Association: Kyu Yusei hogohou ka ni oite jisshi sareta yusei sisou ni motoduku yusei shujutu oyobi jinko ninshin chuzetu ni taisuru hoshou tou no tekisetuna soti wo motomeru ikensho [JBA announcement to seek compensation to forced operation, and abortion under Eugenic Protection Act] (February 16, 2017). Available at: https://www. nichibenren.or.jp/library/ja/opinion/report/data/2017/opinion_170216_07.pdf (accessed on 5 ${ }^{\text {th }}$ November 2018).

43 The Mainichi Shimbun, Kyu yusei hogo ho kyosei funin shujutu issei teiso [Litigation to seek damage for forced abortion under Eugenic Protection Act] (June 3, 2018). Available at: https://mainichi.jp/articles/20180531/ddw/090/040/005000c (accessed on $5^{\text {th }}$ November 2018).

44 The Nikkei Shimbun, Kyu yusei hogo hou ka no kyosei funin [Forced abortion under ex] (May 17, 2018). Available at https://www.nikkei.com/article/DGXMZO30612080X10C18A5CC0000/ (accessed on $5^{\text {th }}$ November 2018).

45 Kokyō you sui iki no suishitu no hozen ni kansuru Hō [Act on the Conservation of water quality of public waters], law no. 181 (1958). Kojō haisui tou no kiseini kansuru Hō [Act on regulations of industrial wastes water, etc.], law no. $182 / 1958$. 
vide remedies to pollutions diseases. Under these two Acts, the scope of the regulations had to be designated beforehand, and the regulations were ineffective. They failed to cover lead and cadmium. In 1970, the Diet finally abolished these statutes and passed the Water Pollution Prevention Act. ${ }^{46}$

The judiciary approved the liability of the illegal inaction of the government under these two Acts in 2004. ${ }^{47}$ The Supreme Court held that governmental inaction was remarkably unreasonable in terms of the meaning, purpose, and nature of power under these laws. The Minister of International Trade and Industry was designated to regulate water pollution from factories, to seek injunctions against the management of factories, and to order the necessary measures. Considering the seriousness of the diseases, the minister should have exercised his designated power immediately. Governmental inaction increased the damage, and the government was liable under the State Redress Act.

This case showed the difficulty of reviewing illegality in the courts, and in 2004, there were demands that the ACLA be revised. If the obligation of administrative agency was clearly stipulated at that time, it would have been easy to determine the illegality of the inaction of the agency. If an agency's power is not clearly stipulated, the judiciary may find it difficult to review cases of illegality.

One court decision notes that the court may find one clear obligation of administrative agency to take action when see the purpose of statutes, and protected interest. The court may admit that there was a clear duty to take action under some circumstances.

The court may also determine the legality of any action or inaction based on the agency's discretion to take such actions. The court may narrow the agency's discretion in some circumstances. Either approach would require that the court clarify an agency's requirements if it finds that it illegally exercised its power. One solution might be the requirement of serious damage to human life, health, and physical bodies.

Under Article 30 of the ACLA, the Court would today have found the discretion of the agency to be capricious or arbitrary. The Court reviews the process of administrative decision-making involving administrative discretion in several phases: fact finding, legal requirement and application, selection among several regulations and effect, and timing.

\subsection{Compelling administrative organs to act}

The 2004 revised ACLA added new types of administrative litigation called suits compelling administrative organs to act. ${ }^{48}$ This suit is divided in two. In one case, the plaintiff is not qualified to apply for permission. The reason to provide mandamus in the ACLA was that the court recognized that administrative inaction may cause serious damage, Thus, Article 3(6) provides mandamus action in case no alternative measure is available other than this litigation, and the plaintiff has legally protected interest.

The other is the case where an applicant is qualified to apply for permission. In this case, the plaintiff applied for permission, but his/her application was remanded or denied. The plaintiff seeks administrative action to issue permissions or to tell him/her what to do.

For example, a public kindergarten rejected an application from a person who has a child with a disability. The Tokyo district court held ${ }^{49}$ that the public kindergarten exercised its discretion in an

46 Suishitu odaku boushi Hō [Water Pollution Prevention Act], law no. 138/1970.

47 Saikō Saibansho [Sup. Ct.] Oct. 15, 2004, Heisei 13(0) no. 1194, 58(7) Saikō Saibansho Minji Hanreishu [Minshu] 1802.

48 Gyosei jiken soshou Hō [Administrative Case Litigation Act], art. 3(6), 37-2.

49 Tokyo Chihō Saibansho [Tokyo Dist. Ct.] Oct. 25, 2006, 1956 Hanrei Jihō [Hanji] 62. 
arbitrary and capricious way. The court compelled the kindergarten to accept the application. This litigation allows a third party, who shall be protected by regulatory administration, to bring forth a suit for incomplete regulation, and to compel administrative organs to act.

Another example of this litigation for families is that of an unmarried couple who submitted a birth certificate to Setagaya ward. The ward rejected the certificate because the father left his relationship to the baby blank and signed the check box of the applicant as "father." This is because he did not want his baby to be registered as an illegitimate child. In Japan, legitimacy with the mother is presumed by birth under Article $772^{50}$ of the Civil Code; however, legitimacy of the child is presumed only to a married father. Thus, under Article 772, even though the child is not the baby of a married father, legitimacy is presumed to a married father. In this case, the ward official asked the man to revise his application, but he refused. The birth certificate was not accepted, and the baby was not registered in the family register.

He brought the matter to court to compel the ward to accept his child's birth certificate. The Tokyo district court held that the rejection of the birth certificate was beyond reasonable discretion and deemed it arbitrary and capricious.

This case shows the problem with Article 772 of the Civil Code that provides for the presumption of the legitimacy of a child. In another case,$^{51}$ a mother was abused by her child's father. She escaped and fell pregnant with another man's child shortly before her divorce. She did not want her child to be the baby of her ex-husband, and thus she could not submit a birth certificate. In another case, a 60-year-old mother brought an action to the Kobe district court alleging that Article 772 was unconstitutional under the equal protection of Article $14^{52}$ of the constitution. In Japan, only a father may bring forth an action to rebut the presumption of legitimacy. The Kobe district court rejected her argument and explained that it is legislative discretion that allows fathers to exclusively rebut the presumption of legitimacy. The Kobe court noted that it is necessary to support divorce litigation, and to protect the privacy of mothers and children in domestic violence cases. The Kobe court encouraged the legislature to support mothers and children who have suffered from domestic violence. This case would go to the Supreme Court for another round of consideration.

\subsection{Ministerial order}

Ministerial orders may work when legislative action is inactive. In unique legislative processes in Japan, ${ }^{53}$ many ministerial ordinances established by ministers work to supplement blank statutes. The constitution allows the administrative branch to write ministerial orders only if law-making power has been designated to them. ${ }^{54}$

One case ${ }^{55}$ regarding child rearing support illustrates that the designated scope is beyond its designation. In this case, the Child Rearing Support $\mathrm{Act}^{56}$ provides support for children whose

50 Minpō [The Civil Code], law no. 89/1896, art. 772.

51 Kobe Chihō Saibansho [Kobe Dist. Ct.] Nov. 29, 2018, Heisei (wa) no. 1653, West Law Japan 2017WLJPCA11296001.

52 Nihonkoku Kenpō [Kenpo] [Japanese Constitution], art. 73(6).

53 TSUJI, Y.: Law Making Power in Japan - Legislative Assessment in Japan. In: Korean Legislation Research, vol. 10, 2016, 1, p. 173.

54 Nihonkoku Kenpō [Kenpo] [Japanese Constitution], art. 73(6).

55 Saikō Saibansho [Sup. Ct.] January 31, 2002, Heisei 8 (gyo tsu) no. 42, 56(1) Saikō Saibansho Minji Hanreishu [Minshu] 246.

56 Jidō fuyō teate-hō [Child Rearing Support Act], law no. 238/1961, art. 4(1). 
parents are divorced, whose fathers have passed away, and for any child under circumstances that are equivalent to these two cases. The ministerial ordinance was given the power to fill the meaning of the term "equivalent." The ministerial order defined the requirement for support to children of unmarried couples and excluded children whose fathers legally recognized them. The administrative branch thought that if a father legally acknowledged his child, he would support that child. The Japanese Supreme Court questioned its interpretation and explained that it is doubtful that child rearing support was no longer necessary on the grounds that fathers would support their children. The Court carefully made a distinction between children of a divorced couple and those of an unmarried couple. The statute may provide support for children of divorced couples. Thus, the Court held that the ordinance unconstitutionally discriminated between these two categories. It was beyond the designation granted by a law-making organ.

\section{EFFECT OF CONSTITUTIONAL DECISIONS ON FAMILIES}

The constitution is based on the values of families, but it is unclear to what extent these values are protected because the term of provision in the Constitution of Japan is abstract. Legislature is required to define the scope and value through statutes. The judiciary will take action after litigation arises or may work to prevent serious damage to human lives and health. The Japanese judiciary may be afraid of its decisions being deemed too influential on Japanese families. On the other hand, the Japanese judiciary is far removed from the people, compared to the legislature and cabinet. Japanese judges are not directly appointed by the people. Only fifteen justices of the Supreme Court are reviewed by popular review under Article $79^{57}$ of the Constitution.

\subsection{Influence on society}

The judiciary may be too afraid to refrain from declaring cases unconstitutional. Judges mainly review cases under concrete judicial reviews. The judiciary is required to render decisions to guarantee foreseeability and to ensure consistency in the application of the law. The judiciary may be required to abstain in judgments that may have an influence on society.

First, after the constitutional decision for the same surname in Article 750 of the Civil Code ${ }^{58}$ in 2015, one CEO brought forth a new action alleging that this provision is unconstitutional. In this case, ${ }^{59}$ President Yoshihisa Aono of Cyozu, a major software company, sought damages under the State Redress Act. He got married in 2001, one year after his company was listed. He chose his wife's family name Nishihata, not Aono. He used Aono as a common family name in his business dealings. In April 2018, in the Tokyo district court, he spoke of the burden of using two different surnames. He noted that it was expensive to change passports, impacted his dealings as a stock holder, and made it difficult to buy plane tickets. He stated that he was required to work quickly for the sake

57 Nihonkoku Kenpō [Kenpo] [Japanese Constitution], art. 79

58 Saikō Saibansho [Sup. Ct.] Dec. 16, 2015, Heisei 26 (o) no. 1023, 69(8) Saikō Saibansho Minji Hanreishu [Minshu] 2586.

59 The Nikkei Shimbun, Fufu bessei erabezu, koseki hou wa iken [It is unconstitutional that family register act obligates to choose either one family name on marriage] (January 9, 2018). Available at: https://www.nikkei.com/article/DGXMZO25442100Z00C18A1CR0000/ (accessed on $5^{\text {th }}$ November 2018). 
of the management of his company, and such wasteful activities caused serious damage. He argued that Article 750 should be deemed unconstitutional. Unlike the 2015 decision, Aono made a new argument. First, he sought to change the Family Register Act ${ }^{60}$ to allow the use of his premarital surname. Second, he argued that a couple, one Japanese and one a foreign national, may use different surnames under the Family Register Act, but this is not the case for Japanese couples. As such, it is unconstitutional under the equality principle of Article $4^{61}$ of the constitution. It is unclear if this case will go to the Japanese Supreme Court. It is not easy for the judiciary to deny it based on the 2015 decision, because Aono brought forward a new claim that the judiciary is required to review. Justice Chiba's concurring opinion reiterated the power balance between the judiciary and the legislature. ${ }^{62} \mathrm{He}$ argued that the scope of judicial decisions should be narrow to regulate later cases as much as possible. He is now retired, but nonetheless, it should be noted that his opinion is one stream of the Japanese Supreme Court.

Second, Kobe's decision ${ }^{63}$ denied the argument that it was unconstitutional that only a father may bring about an action to rebut the presumption of legitimacy. An inferior court may render an experimental decision and does not have to worry about the outcomes and influences of such a decision as much as the Japanese Supreme Court, who is required to render a judgement that is uniform. The inferior court may be vacated or remanded by the higher court. It may encourage the legislature to amend or abolish provisions of statutes. In the Down syndrome case, the Tokyo district court announced the provision of POEA restricting a person with Down syndrome. As Justice Chiba ${ }^{64}$ stated in 2014, judges are required to review concrete cases, and narrow their decision based on the issue. Other cases that have the same legal issue would lose their predictability, as well as the equal principle of requesting equal treatment.

In 2008, the Japanese Supreme Court ${ }^{65}$ held that Article 3(1) of the Nationality Act that denied nationality to children born of a Japanese father and an unmarried foreign national was unconstitutional; it only allowed for the legal recognition of the unborn child. The Court questioned if legislative facts of the Nationality Act in 1984 is still maintained. When this provision was established, its purpose was reasonable: to demand the marriage between a Japanese father and a foreign mother that connects them to Japan. The Court held that the aforementioned reasonableness was lost due to a change of legislative fact. The scope of this decision only covers families who argued in court as plaintiffs. A court decision is required to ensure equal treatment. In Japan, foreign parents or mothers submit birth certificates to municipal offices. Within 30 days of the birth, the parents or mother submit the birth certificate along with a certificate of eligibility for residence status to the immigration bureau. The baby will then be classified as a foreign national, not as a Japanese citizen.

Thus, if the scope of the unconstitutional decision only covers plaintiffs, unequal treatment would arise. Unless the legislature amends this unconstitutional provision, the local or national government needs to adhere to an unconstitutional decision by ignoring a procedure based on an unconstitutional provision. One of the most famous unconstitutional decisions is that of a parricide

60 Koseki Hō [Family Register Act], law no. 224/1947.

61 Nihonkoku Kenpō [Kenpo] [Japanese Constitution], art. 14.

62 CHIBA, K.: Iken-Shinsa [Judicial review]. Yuhikaku, 2017, p. 122.

63 Kobe Chihō Saibansho [Kobe Dist. Ct.] Nov. 29, 2018, Heisei (wa) no. 1653, West Law Japan 2017 WLJPCA11296001.

64 Katsumi Chiba, J., concurring.

65 Saikō Saibansho [Sup. Ct.] June 4, 2008, Heisei 18 (gyo tsu) no. 135, 62(6) Saikō Saibansho Minji Hanreishū [Minshū] 101 (Japan); Saikō Saibansho [Sup. Ct.] June 4, 2008, Heisei 19 (gyo tsu) 164, 228 Saikō Saibansho Minji Hanreishū [Minshū] 101. 
case from 1973; it took 22 years to change the unconstitutional provision. ${ }^{66}$ While the legislature was deleted, the prosecutor applied a general murder provision, which was not an unconstitutional decision. It is the judiciary's responsibility to answer for what law is used in the courts. It is unproblematic for judges, even if a prosecutor used an unconstitutional provision.

These cases illustrate that unconstitutional decisions that influence society have no clear standard for the disciplining of judges. Judges are required to gain the trust of the people through their judgments. Judges may be required to provides guideline for legislature what to do in law making process after judicial decision. As in the Osaka High Court decision, judges may declare the constitutionality of a provision on an issue, but may still keep the legality for monetary responsibility under the inaction of the legislature. Thus, constitutional and unconstitutional decisions influence and impact society.

\subsection{Timeline of decisions}

The court may restrict the timeline of unconstitutional decisions by limiting unconstitutional decisions. On September 4, 2013, the Japanese Supreme Court ${ }^{67}$ held that Article 900 of the Civil Code that restricts the legal portion of the inheritance of illegitimate children to half of that of legitimate children to be unconstitutional. The Court's order caused confusion because the Court once held it as constitutional in 1995. The 1995 Court order emphasized the importance of legal marriage, and it is within the scope of legislative discretion to restrict the inheritance of an illegitimate child.

In Japan, the inheritance procedure starts when a person passes away. If there is a will, the deceased's successor observes it. Article $900^{68}$ of the Civil Code was soon amended. The new provision applies only in cases where a person has passed away one day after September 4, 2013, the day that the unconstitutionality was proclaimed. The amended provision covers only cases where there are legitimate and illegitimate successors, not cases where the deceased only has legitimate or illegitimate successors.

The Court carefully reviewed and explained this 2015 case which was brought to the trial court on July 1, 2001. Thus, to retain predictability and equal treatment, the Ministry of Justice explained that the amended provision applies to inheritance that starts after July 1, 2001, except in cases where the division of an estate was already completed.

This case illustrates that the judiciary may shut down the scope of a decision by adding an explanation to the legislature for retroactivity. Even under the Civil Law of the country, a judicial decision is also important under the rule of law. The core principle in the reasoning of a decision that binds later cases is called ratio decidendi. The other remaining part that does not regulate later cases is called obiter dictum.

The problem is how the judiciary may emphasize and include core legal principles and others in its reasoning. Dissenting opinions in family law cases show that minority opinions can influence later cases. The serious problem for predictability is that Japanese courts may not know how and

66 TSUJI, Y.: Decisions That Declared Laws Unconstitutional and Their Impact on Japanese Families. In: ILSA Journal of International \& Comparative Law, 24, 2017, 1, Article 2, at 49.

67 Saikō Saibansho [Sup. Ct.] Sept. 4, 2013, Heisei 24 (kyo) no. 985, 67(6) Saikō Saibansho Minji Hanreishū [Minshū] 1320.

68 Minpō [The Civil Code], art. 900. 
which factor the judiciary emphasizes in its reasoning for binding power in a judicial precedent. Unlike in common law countries, the Japanese judiciary tends to write its decisions by citing precedent in abstract form, and does not explain how cases are different from past precedents.

\section{CONCLUSION}

The cases in this study show how legislative inaction has caused serious damage to human life, health, and voting rights. In voting rights cases, the Japanese Supreme Court is obligated to review the process of legislation. However, under concrete judicial review, abstract reviews are the exception, and the Court is obligated to review evidence submitted by the parties. Even under concrete judicial review, the Court needs to review if the constitutional rights of minorities are protected. The Court devised some precedent, and the legislature revised the Administrative Case Litigation Act to expand the scope of judicial review. One piece of litigation, public law-related actions, allowed the judiciary exercise of performing broad judicial reviews.

Under the revised Japanese ACLA, several litigations are available: revocation of administrative measures, revocation of adjudication, confirmation of nullification, confirmation of illegal inaction, compelling the administrative organs to act, and injunctions. In these cases, the judiciary does not perform binding actions, but may show how the legislature should provide or amend the text of the statute in question. If the explanation of the judiciary is incomplete, the legislature cannot receive its message and would not work well to amend statutes. Under the parliamentary system in Japan, the administrative branch is so powerful that the decision-making process of the legislature is weak. Judicial decisions should work to show the limits of broad legislative discretion that is granted by the constitution. If legislative inaction leads to the endangerment of human lives and health, the Court should actively rule that the government is liable. One way to do this is to rule in favor of monetary compensation for damages under the State Redress Act. It might allow the judiciary to exercise abstract judicial reviews. Thus, mandamus action under the ACLA would work better and would allow the judiciary to encourage administrative agencies to take action. Some inferior courts are now reviewing the availability of some mandamus actions. Ministerial order plays an important role in Japanese law making process to clarify ambiguity in statute. Sometimes the court would announce that ministerial ordinances are beyond the designated power that it received from the parliament.

Lastly, while Justice Chiba argues that judicial decisions should be rendered so as to narrowly bind later cases, judicial decisions on families would still influence society even though they are constitutional decisions to approve legislative discretion. Even in civil law countries, judges are obliged to connect current cases with precedents. Dissenting opinions in family law cases show that minority opinions may influence later cases.

Japanese public law scholars are obliged to help the people review the reasoning of decisions made by the judiciary. The Japanese judiciary has a duty to gain the trust of the people through its decisions. 


\section{Bibliography:}

\section{Books}

ASHIBE, M.: Kenpō [Constitution], 2015.

CHIBA, K.: Iken-Shinsa [Judicial review]. Yuhikaku, 2017.

SAKURAI, K. - HASHIMOTO, H.: Gyosuei Hō [Administrative law]. Kobundo, 2015.

\section{Articles}

Japan Bar Association: Kyu Yusei hogohou ka ni oite jisshi sareta yusei sisou ni motoduku yusei shujutu oyobi jinko ninshin chuzetu ni taisuru hoshou tou no tekisetuna soti wo motomeru ikensho [JBA announcement to seek compensation to forced operation, and abortion under Eugenic Protection Act] (February 16, 2017). Available at: https://www.nichibenren.or.jp/library/ja/opinion/report/data/2017/opinion_170216_07.pdf (accessed on 5 $5^{\text {th }}$ November 2018).

OHKAWA, S.: Meiji Minpō ni okeru Koui Nouryoku no seigen [Restriction of legal capacity under Meiji Civil Code]. In: Ritsumeikan Ho gaku, vol. 240, 1995. Available at: http://www.ritsumei.ac.jp/acd/cg/law/lex/95-2/ookawa.htm (accessed on $5^{\text {th }}$ November 2018).

TSUJI, Y.: Decisions That Declared Laws Unconstitutional And Their Impact On Japanese Families. In: ILSA Journal of International \& Comparative Law, Vol. 24, 2017, 1, Article 2. Available at: https://nsuworks.nova.edu/ilsajour$\mathrm{nal} / \mathrm{vol} 24 / \mathrm{iss} 1 / 2$ (accessed on $5^{\text {th }}$ November 2018).

TSUJI, Y.: Law Making Power in Japan - Legislative Assessment in Japan. In: Korean Legislation Research. vol. 10, 2016, 1 .

TSUJI, Y.: Reflection of Public Interest in the Japanese Constitution: Constitutional Amendment. In: Denver Journal of International Law \& Policy, Vol. 46, 2018, 2, p. 159, 163.

\section{Constitution and statutes}

Dai Nihon Teikoku Kenpō (Meiji Kenpō) [Meiji Constitution].

Gyosei jiken soshou Hō [Administrative Case Litigation Act], law no. 139/1962, art. 3,3(5),3(6), 4,5,6,37-2.

Jidō fuyō teate-hō [Child Rearing Support Act], law no. 238/1961, art. 4(1).

Kojo haisui tou no kiseini kansuru Hō [Act on regulations of industrial wastes water, etc.], law no. 182/1958.

Kokka Baishou Hō [State Redress Act], law no. 22/1947.

Kokyo you sui iki no suishitu no hozen ni kansuru Hō [Act on the Conservation of water quality of public waters], law no. 181/1958.

Koseki Hō [Family Register Act], law no. 224/1947.

KŌshoku Senkyo Hō [Japanese Public Officer Election Act], law no. 60/2015, art. 11(1)ii, iii, 68, 204,205(1).

Minpō [The Civil Code], law no. 89/1896, art. 772, 900.

Nihon-Koku Kenpō [Constitution of Japan] May 3, 1947, art. 14, 15, 41, 73(6), 79.

Saibansho Hō [Court Act], law no. 59/1947, art. 3.

Suishitu odaku boushi Hō [Water Pollution Prevention Act], law no. 138/1970.

Yusei hogo Hō [Eugenic Protection Act], law no. 165/1948 (abolished).

Decisions

Kobe Chihō Saibansho [Kobe Dist. Ct.] Nov. 29, 2018, Heisei (wa) no. 1653, West Law Japan 2017WLJPCA11296001.

Osaka Kotō Saibansho [Osaka High Ct.] Sept. 27, 2013, Heisei 25 (gyo ko) no. 45, 2234 Hanrei Jihō 29, West Law Japan, 2013WLJPCA09276001. 
Saikō Saibansho [Sup. Ct.] Nov. 21, 1985, Showa 50(0) no. 1240, 39(7) Saikō Saibansho Minji Hanreishu [Minshu] 1512.

Saikō Saibansho [Sup. Ct.] January 31, 2002, Heisei 8(gyo tsu) no. 42, 56(1) Saikō Saibansho Minji Hanreishu [Minshu] 246.

Saikō Saibansho [Sup. Ct.] Oct. 15, 2004, Heisei 13(0) no. 1194, 58(7) Saikō Saibansho Minji Hanreishu [Minshu] 1802.

Saikō Saibansho [Supreme Court] Sept. 14, 2005, Heisei 13 (gyo tsu) no. 82, 59(7) Saikō Saibansho Minji Hanreishu [Minshu] 2087.

Saikō Saibansho [Sup. Ct.] June 4, 2008, Heisei 18 (gyo tsu) no. 135, 62(6) Saikō Saibansho Minji Hanreishū [Minshū] 101.

Saikō Saibansho [Sup. Ct.] June 4, 2008, Heisei 19 (gyo tsu) 164, 228 Saikō Saibansho Minji Hanreishū [Minshū] 101.

Saikō Saibansho [Sup. Ct.] Sept. 4, 2013, Heisei 24 (kyo) no. 985, 67(6) Saikō Saibansho Minji Hanreishū [Minshū] 1320.

Saikō Saibansho [Sup. Ct.] Dec. 16, 2015, Heisei 26 (o) no. 1023, 69(8) Saikō Saibansho Minji Hanreishu [Minshu] 2586.

Tokyo Chihō Saibansho [Tokyo Dist. Ct.] Nov. 28, 2002, Heisei 12 (wa) no. 502, 1114 Hanrei Taimuz [Hanta] 93.

Tokyo Kotō Saibansho [Tokyo High Ct.] Sept. 14, 2005, Heisei 13 (gyo tsu) no. 82, 59(7) Saikō Saibansho Minji Hanreishu [Minshu] 2087.

Tokyo Chihō Saibansho [Tokyo Dist. Ct.] Oct. 25, 2006, 1956 Hanrei JihŌ [Hanji] 62.

Tokyo Chihō Saibansho [Tokyo Dist. Ct.] March 14, 2013, Heisei 23 (gyo u) no. 63, 1388 Hanrei Taimuz [Hanta] 62.

\section{Newspapers}

The Mainichi Shimbun, Kagakuno na no motoni [Under the name of science] (8, June, 2018). Available at: https:// mainichi.jp/articles/20180607/ddm/041/040/141000c (accessed on $5^{\text {th }}$ November 2018).

The Mainichi Shimbun, Editorial: Kyosei funin shujutu no chousa [Editorial: investigation on forced abortion]. Available at: https://mainichi.jp/articles/20180513/ddm/005/070/003000c (accessed on $5^{\text {th }}$ November 2018).

The Mainichi Shimbun, Kyu yusei hogo ho kyosei funin shujutu issei teiso [Litigation to seek damage for forced abortion under Eugenic Protection Act] (June 3, 2018). Available at: https://mainichi.jp/articles/20180531/ ddw/090/040/005000c (accessed on $5^{\text {th }}$ November 2018).

The Nikkei Shimbun, Kyu yusei hogo hou ka no kyosei funin [Forced abortion under ex] (May 17, 2018). Available at: https://www.nikkei.com/article/DGXMZO30612080X10C18A5CC0000/ (accessed on 5th November 2018).

The Nikkei Shimbun, Fufu bessei erabezu, koseki hou wa iken [It is unconstitutional that family register act obligates to choose either one family name on marriage] (January 9, 2018). Available at: https://www.nikkei.com/article/ DGXMZO25442100Z00C18A1CR0000/ (accessed on $5^{\text {th }}$ November 2018).

\section{Contact information}

Yuichiro TSUII, associate professor tsuji.yuichiro.gm@u.tsukuba.ac.jp

Faculty of Humanities and Social Sciences

University of Tsukuba

1-1-1 Tenno dai, Tsukuba city, Ibaraki, 305-8571

Japan 